\title{
Genetic analyses of Casuarinas using ISSR and FISSR markers
}

\author{
R. Yasodha ${ }^{1}$, M. Kathirvel ${ }^{2}$, R. Sumathi ${ }^{1}$, K. Gurumurthi ${ }^{1}$, Sunil Archak $^{2}$ \& \\ J. Nagaraju ${ }^{2, *}$ \\ ${ }^{1}$ Division of Plant Biotechnology, Institute of Forest Genetics and Tree Breeding, Coimbatore 641002, India; \\ ${ }^{2}$ Laboratory of Molecular Genetics, Centre for DNA Fingerprinting and Diagnostics, Hyderabad 500076, \\ India; *Author for correspondence (Phone: +91-40-715-1344; Fax: +91-40-715-5610; E-mails: jnagaraju@, \\ cdfd.org.in, jnagaraju@mailcity.com)
}

Received 11 August 2003 Accepted 2 March 2004

Key words: Allocasuarina, Casuarina, FISSR-PCR, ISSR-PCR

\begin{abstract}
Inter simple sequence repeat polymerase chain reaction (ISSR-PCR) was used for the genetic analysis of the six species of Allocasuarina, five species of Casuarina and 12 superior performing selections of $C$. equisetifolia L. We also fingerprinted C. equisetifolia L. selections using Fluorescent-ISSR-PCR (FISSR-PCR), an improvised ISSR-PCR assay. The ISSR analysis provided information on the frequency of various simple sequence repeats in the casuarina genome. The di-nucleotide repeats were more common, among which $(\mathrm{CA})_{n}$ and its complementary nucleotide $(\mathrm{GT})_{n}$ repeat motifs amplified relatively higher number of bands with an average of $6.0 \pm 3.5$ and $6.3 \pm 1.8$ respectively. Eleven species of casuarinas were amplified with 10 primers anchored either at $5^{\prime}$ or $3^{\prime}$ end. A total of 253 PCR products were obtained and all were polymorphic, out of which 48 were specific to Allocasuarina and 36 were specific to Casuarina genus. Genetic similarity among the species was 0.251 . A UPGMA dendrogram grouped all the Casuarina species together. The 12 superior performing selections of $C$. equisetifolia $\mathrm{L}$. produced 57 polymorphic ISSR markers while the FISSR assay revealed 105 polymorphic markers. The primer CRR(ATT) $_{4}$ distinguished all the selections. DNA profiles obtained with ISSR and FISSR assays would serve as a reference library for the establishment of clonal identity in casuarinas.
\end{abstract}

\section{Introduction}

The members of the family Casuarinaceae are commonly known as casuarinas. They are monoecious or dioecious trees or shrubs, having unique needle like branchlets with many articles. Currently, casuarinas are grouped under four genera (Wilson \& Johnson, 1989), which encompass over 90 species (Moncur, Boland \& Harbard, 1997). Among the four genera, the species of Casuarina $\mathrm{L}$. Johnson and Allocasuarina L. Johnson are commercially cultivated in many tropical and subtropical regions of the world while the other two genera Gymnostoma L. Johnson and Ceuthostoma L. Johnson occur as wild species only.

Casuarina $(2 n=18)$ comprises about 17 species distributed throughout Southeast Asia, and Australia (Pinyopusarerk \& House, 1993) whereas Allocasuarina consisting of 59 species are endemic to Australia (Wilson \& Johnson, 1989). They are considered to be the nearest relatives of the genus Casuarina since they share many common morphological features. The basic chromosome number of Allocasuarina varies from $n=10$ to $n=14$. Polyploidy, particularly tetraploidy is known to be prevalent in some species like $A$. luehmanii 
$(2 n=56)$ and $A$. littoralis $(2 n=44)$. Phylogenetic and taxonomic relationships within the species of casuarinas have been studied using the size and number of chromosomes, pattern of geographical distribution (Barlow, 1959, 1983) and diversification in the morphological characteristics (Wilson \& Johnson, 1989) to distinguish the members of Allocasuarina and Casuarina. Recently, $r b c \mathrm{~L}$ and plastid $m a t \mathrm{~K}$ sequences were used for the genetic analysis of Casuarinaceae (Sogo et al., 2001) and the study was further extended to decipher the phylogeny of 76 species demonstrating the monophyly of the four genera and examining the relationships within the family (Steane, Wilson \& Hill, 2003).

Although about 15 species of Casuarina and Allocasuarina are recognized for multiple utilization, only C. equisetifolia $\mathrm{L}$. is cultivated widely in many countries (Doran \& Hall, 1983; Pinyopusarerk \& House, 1993) accounting for about $1.4 \%$ of tree plantations of the casuarinas (FAO, 1995). This commercial and silvicultural importance of C. equisetifolia $\mathrm{L}$. has led to the establishment of multinational provenance trials co-ordinated by CSIRO, Australia (Pinyopusarerk et al., 1996). The species is propagated by cladode cuttings (Gurumurthi \& Bhandari, 1988) and yield gain is achieved through clonal plantations using genetically divergent and productive clones (Ahuja \& Libby, 1993). In India, major effort is directed towards production of improved planting stocks through selection of superior performers from plantations/provenances and their vegetative propagation. Additionally, seed orchard raised with selected clones can provide good quality seeds for plantations if vegetative propagules fall short of demand. The optimal utilisation of diversity requires genetic charaterisation of the stocks and identification of the selected clones in the early stage.

Morphological characters have been used to estimate genetic divergence of clonal selections of C. equisetifolia L. (Kumar \& Gurumurthi, 2000). Genetic variation at the population level has been studied by using RAPD markers in C. equisetifolia L. (Ho et al., 2002). RAPD variation in casuarina of Taiwan has revealed that most plants in Taiwan are closely related but not typical C. equisetifolia L. indicating introgressive hybridisation among C. equisetifolia, C. glauca and C. cunninghamiana (Ho, Yang \& Hsiao, 2002).
Our goal in the present study is to generate a reliable DNA based marker system for the characterisation of Casuarinaceae in general and C. equisetifolia L. in particular. Among many different types of DNA markers, the markers based on microsatellites or simple sequence repeats (SSRs) provide a co-dominant, highly reproducible and genetically informative marker system (Tautz, 1989; Weber \& May, 1989; Zietkiewicz, Rafalski \& Labuda, 1994; Broun \& Tanksley, 1996). However, as of today the information on SSR loci is not available in Casuarinaceae. An alternative method, the Inter Simple sequence Repeat-PCR (ISSR-PCR), which takes advantage of the ubiquitously distributed SSRs in the eukaryotic genomes, provides an opportunity to obtain highly reproducible markers without prior knowledge of the DNA sequence, for various genetic analyses.

ISSR-PCR has been used widely in plants for the analysis of genetic relationships between and within species (Salimath et al., 1995; Tsumura, Ohba \& Strauss, 1996; Fang, Krueger \& Roose, 1998; Ge \& Sun, 1999; Ajibade, Weeden \& Chite, 2000; Chapman, Parh \& Oraguzie, 2000; Huang \& Sun, 2000; Martin \& Sanchez-Yelamo, 2000), assessment of hybridisation in natural populations (Wolfe, Xiang \& Kephart, 1998) and germplasm analysis (Proven, Powell \& Waugh, 1996; Gilbert et al., 1999). Further, ISSR-PCR is useful in fingerprinting and characterisation of accessions (Fang et al., 1997; Moreno, Martin \& Ortiz, 1998; Blair, Panaud \& McCouch, 1999; Charters \& Wilkinson, 2000) and identification of cultivars and varieties (Fang \& Roose, 1997; Prevost \& Wilkinson, 1999; Zavodna et al., 2000; Kumar et al., 2001). Recently, Nagaraju et al., (2002a, b) have illustrated the power of an improved method of ISSR-PCR called fluorescent ISSR-PCR (FISSRPCR) in revealing differences among closely related genotypes. The advantages of this technique over ISSR-PCR include increased number of bands per primer, requirement of very low quantity $(2-5 \mathrm{ng})$ of template DNA and high throughput analysis.

The present work was taken up with an objective of establishing an efficient and reproducible marker system based on ISSR-PCR for the identification of clonal selections of Casuarina equisetifolia. We also attempted to find out genetic relationships among a few species of Allocasuarina and Casuarina with ISSR-PCR markers. 


\section{Materials and methods}

\section{Plant material and DNA extraction}

Six species of the genus Allocasuarina and five species of the genus Casuarina were used in the present study (Table 1). Seeds (bulked) were obtained from Australian Tree Seed Centre, CSIRO, Australia and the location of the seed samples collected are shown in Figure 1. Seeds were germinated on sterilised sand and about 20 day old, 20 individuals per species were pooled for DNA extraction.

The Casuarina equisetifolia trees were selected from two different plantations raised at Chidambaram $\left(11^{\circ} 54^{\prime \prime} \mathrm{N}, 71^{\circ} 41^{\prime \prime} \mathrm{E}\right)$ and Chengalpet $\left(13^{\circ} 00^{\prime \prime} \mathrm{N}, 80^{\circ} 11^{\prime \prime} \mathrm{E}\right)$. Among 55 candidate plus tree selections raised as hedges, 12 superior performers were selected based on their silvicultural characteristics, viz., height, diameter at breast height, crown architecture and main bole volume and have been used extensively for establishing commercial clonal plantations (Table 2).
These 12 selections (called 'clones' henceforth, solely to indicate the mode of propagation from the selected plants) were chosen for DNA fingerprinting.

Fresh, growing tips of needles of the clones were used for DNA extraction. The plant materials were ground to powder in sterilised pestle and mortar in the presence of liquid Nitrogen and the DNA was extracted as described previously (Doyle $\&$ Doyle, 1990). DNA was purified and quantified according to standard procedures.

\section{PCR analysis}

In a preliminary study, a total of 37 primers (10 primers of University of British Columbia and 27 in house designed and synthesised at Centre for DNA Fingerprinting and Diagnostics, Hyderabad, India) were tested (20 on two species of Allocasuarina - A. decaisneana and A. dielsiana; 37 on two clones of C. equisetifolia L. - CHCE890903 and CPCE890301) (Table 3). Based on the number of polymorphic bands produced, 10 and 7 primers

Table 1. Details of seed sources and basic chromosome number of Allocasuarina and Casuarina species used for ISSR studies

\begin{tabular}{|c|c|c|c|c|c|}
\hline S. no. & Name of the species & $\begin{array}{l}\text { Chromosome } \\
\text { number }(n)\end{array}$ & $\begin{array}{l}\text { CSIRO seed } \\
\text { lot number }\end{array}$ & Origin & $\begin{array}{l}\text { Number of trees used } \\
\text { for bulking seeds }\end{array}$ \\
\hline 1 & $\begin{array}{l}\text { Allocasuarina decaisneana } \\
\text { (F. Muell.) L. Johnson }\end{array}$ & 14 & 17364 & $\begin{array}{l}\text { Ooraminna } \\
\text { NT }\end{array}$ & 14 \\
\hline 2 & $\begin{array}{l}\text { Allocasuarina dielsiana (C. Gardner) } \\
\text { L. Johnson }\end{array}$ & 14 & 13215 & $\begin{array}{l}\text { Rothsay townsite } \\
\text { WA }\end{array}$ & 5 \\
\hline 3 & $\begin{array}{l}\text { Allocasuarina Huegeliana (Miq.) } \\
\text { L. Johnson }\end{array}$ & 13 & 15801 & $\begin{array}{l}\text { Sanford Rock } \\
\text { WA }\end{array}$ & 4 \\
\hline 4 & $\begin{array}{l}\text { Allocasuarina littoralis (Salisb.) } \\
\text { L. Johnson }\end{array}$ & 11 & 13876 & $\begin{array}{l}\text { Gordan and } \\
\text { Chilicks QLD }\end{array}$ & 5 \\
\hline 5 & $\begin{array}{l}\text { Allocasuarina luehmannii } \\
\text { (R. Baker) L. Johnson }\end{array}$ & 14 & 13880 & $\begin{array}{l}\text { Mt. Molloy } \\
\text { Mareeba QLD }\end{array}$ & 30 \\
\hline 6 & $\begin{array}{l}\text { Allocasuarina torulosa (Aiton) } \\
\text { L. Johnson }\end{array}$ & 12 & 13377 & Mt. Lewis QLD & 10 \\
\hline 7 & Casuarina cristata Miq. & 9 & 17757 & $\begin{array}{l}\text { West of Dalby } \\
\text { Moonie Hwy QLD }\end{array}$ & 4 \\
\hline 8 & Casuarina cunninghamiana Miq. & 9 & 13513 & $\begin{array}{l}36 \mathrm{~km} \mathrm{NE} \text { of } \\
\text { Oasis QLD }\end{array}$ & 10 \\
\hline 9 & Casuarina equisetifolia $\mathrm{L}$. & 9 & 19129 & $\begin{array}{l}\text { Lakei/sibur } \\
\text { Bako, Malaysia }\end{array}$ & 4 \\
\hline 10 & Casuarina glauca Sieb. Ex Spreng. & 9 & 15941 & $\begin{array}{l}\text { Burrum } \\
\text { Heads QLD }\end{array}$ & 9 \\
\hline 11 & Casuarina obesa Miq. & 9 & 15796 & Murchison River WA & 10 \\
\hline
\end{tabular}




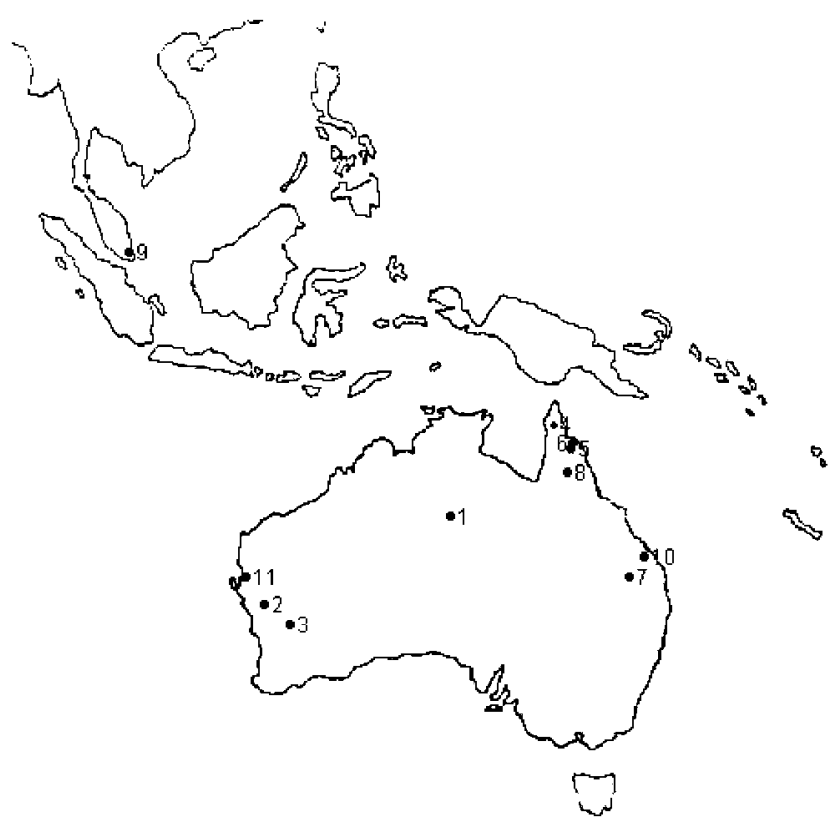

Figure 1. Location of collection of Allocasuarina and Casuarina species used in the study. (The numbers represent the order of species given in Table 1.)

Table 2. List of clones of Casuarina equisetifolia used for ISSR studies

\begin{tabular}{cllllllll}
\hline S. no & Clone no & Sex & Height $(\mathrm{cm})$ & $\mathrm{DGL}^{\mathrm{b}}(\mathrm{cm})$ & $\mathrm{DBH}^{\mathrm{c}}(\mathrm{cm})$ & $\begin{array}{l}\mathrm{MBV}^{\mathrm{d}} \\
(\mathrm{cm})^{3}\end{array}$ & $\mathrm{FV}^{\mathrm{e}}(\mathrm{cm})^{3}$ & Pole value \\
\hline 1 & & & & & & & & \\
2 & CHCE892002 & M & 1574 & 8.73 & 6.69 & 47,084 & 6514 & 32,948 \\
3 & CHCE890304 & M & 1376 & 9.01 & 6.69 & 43,844 & 6785 & 38,545 \\
4 & CHCE890903 & M & 1650 & 10.62 & 8.55 & 73,042 & 9995 & 60,682 \\
5 & CHCE890905 & M & 1450 & 8.52 & 5.57 & 41,313 & 5618 & 31,384 \\
6 & CHCE892703 & F & 1650 & 7.57 & 6.22 & 37,112 & 5170 & 24,919 \\
7 & CHCE890102 & F & 1340 & 8.69 & 6.77 & 39,718 & 6535 & 26,170 \\
8 & CPCE891501 & M & 1574 & 8.81 & 6.85 & 47,950 & 6701 & 31,905 \\
9 & CPCE890110 & M & 1425 & 8.40 & 7.16 & 39,465 & 6544 & 30,549 \\
10 & CPCE893903 & M & 1350 & 7.01 & 6.04 & 26,038 & 4586 & 21,374 \\
11 & CPCE890401 & M & 1340 & 7.26 & 5.88 & 27,722 & 4680 & 18,350 \\
12 & CPCE891802 & F & 1340 & 7.72 & 7.06 & 31,346 & 5868 & 23,355 \\
\hline
\end{tabular}

${ }^{\mathrm{a}} \mathrm{M}=$ male, $\mathrm{F}=$ female; ${ }^{\mathrm{b}}$ diameter at ground level; ${ }^{\mathrm{c}}$ diameter at breast height; ${ }^{\mathrm{d}}$ main bole volume; ${ }^{\mathrm{e}}$ frustum volume.

were selected for analysing the 11 species of casuarinas and 12 clones of $C$. equisetifolia $\mathrm{L}$., respectively. The selected ISSR primers, which, include di-, tri-, and tetra-nucleotide repeats used for the analysis of species of Casuarina and Allocasuarina and the clones of $C$. equisetifolia $\mathrm{L}$. are shown in Tables 4 and 5, respectively. ISSR-PCR amplifications were carried out in the reaction mixtures of $10 \mu 1$ containing 1x PCR buffer (MBI Fermentas), $0.1 \mathrm{mM}$ each of dCTP, dGTP, dTTP and dATP, $2.5 \mathrm{mM} \mathrm{MgCl} 2,0.8 \mu \mathrm{M}$ primer, 1.0 unit of Taq DNA polymerase (MBI Fermentas) and $30 \mathrm{ng}$ of template DNA. All the PCR reactions were carried out in PE 9600 Thermal Cycler (Perkin Elmer Corp., USA) using the following reaction conditions: $94^{\circ} \mathrm{C}$ for $3 \mathrm{~min}$. initial dena- 
Table 3. List of ISSR Primers used for preliminary screening

\begin{tabular}{|c|c|c|c|c|}
\hline \multirow[t]{2}{*}{ Primer code } & \multirow[t]{2}{*}{ Primer sequence $5^{\prime}-3^{\prime}$} & \multicolumn{3}{|c|}{ No. of bands amplified } \\
\hline & & Clones & Species & Average \\
\hline \multicolumn{5}{|l|}{$5^{\prime}$ anchored } \\
\hline $\mathrm{R}(\mathrm{CA})_{7}$ & GRT RCY GRT R $(\mathrm{CA})_{7}$ & 10 & 7 & 8.5 \\
\hline $\mathrm{R}(\mathrm{TG})_{7}$ & RYA CRY RCA R $(\mathrm{TG})_{7}$ & 3 & 5 & 4.0 \\
\hline $\mathrm{Y}(\mathrm{TG})_{7}$ & YAY GYA CAY $(\mathrm{TG})_{7} \mathrm{~T}$ & 0 & 5 & 2.5 \\
\hline $\mathrm{T}(\mathrm{GT})_{9}$ & CRT AY $(\mathrm{GT})_{9}$ & 8 & 7 & 7.5 \\
\hline $\mathrm{T}(\mathrm{GA})_{8}$ & YGY RAY $(\mathrm{GA})_{8}$ & 3 & 8 & 5.5 \\
\hline $\mathrm{C}(\mathrm{GA})_{7}$ & RAY RAT AY $(\mathrm{GA})_{7}$ & 4 & 9 & 6.5 \\
\hline$(\mathrm{CA})_{7} \mathrm{C}$ & GYT ACT GYT $(\mathrm{CA})_{7} \mathrm{C}$ & 0 & 7 & 3.5 \\
\hline $\mathrm{G}(\mathrm{ATT})_{4}$ & $\mathrm{YCY}$ RRG $(\mathrm{ATT})_{4}$ & 6 & ND & ND \\
\hline $\mathrm{AT}(\mathrm{ATT})_{4}$ & RYGAT $(\mathrm{ATT})_{4}$ & 4 & ND & ND \\
\hline $\mathrm{CRR}(\mathrm{ATT})_{4}$ & $\mathrm{AGC} \mathrm{RR(ATT)})_{4}$ & 4 & 5 & 4.5 \\
\hline TC(ATT) $)_{4}$ & GAR TY $(\mathrm{ATT})_{4}$ & 3 & ND & ND \\
\hline $\mathrm{T} 3(\mathrm{ATT})_{4}$ & RA TYT (ATT) $)_{4}$ & 1 & ND & ND \\
\hline $\mathrm{GA}(\mathrm{ATT})_{4}$ & $\mathrm{AGY}$ GR $(\mathrm{ATT})_{4}$ & 3 & ND & ND \\
\hline $\mathrm{AA}(\mathrm{AAT})_{4}$ & TR AAR $(\mathrm{AAT})_{4}$ & 2 & ND & ND \\
\hline $\mathrm{CT}(\mathrm{AAT})_{4}$ & RYR CY $(\mathrm{AAT})_{4}$ & 0 & ND & ND \\
\hline $\mathrm{A} 3(\mathrm{AAT})_{4}$ & ACR ARA $(\mathrm{AAT})_{4}$ & 0 & ND & ND \\
\hline $\mathrm{TA}(\mathrm{CAG})_{4}$ & ARR TY $(\mathrm{CAG})_{4}$ & 4 & 9 & 6.5 \\
\hline $\mathrm{RA}(\mathrm{GCT})_{6}$ & AYA RA $(\mathrm{GCT})_{6}$ & 5 & 10 & 7.5 \\
\hline $\mathrm{Y}(\mathrm{ACC})_{7} \mathrm{~A}$ & $\mathrm{YYR}$ AY $(\mathrm{ACC})_{7} \mathrm{~A}$ & 6 & 6 & 6.0 \\
\hline$(\mathrm{CTT})_{7}$ & & 0 & ND & ND \\
\hline$(\mathrm{CAC})_{6}$ & & 0 & 0 & 0 \\
\hline$(\mathrm{AGC})_{10}$ & & 0 & 0 & 0 \\
\hline $\mathrm{Y}(\mathrm{GCC})_{4}$ & TGAGY $(\mathrm{GCC})_{4}$ & 9 & 7 & 8.0 \\
\hline UBC861 & $(\mathrm{ACC})_{6}$ & 3 & ND & ND \\
\hline UBC862 & $(\mathrm{AGC})_{6}$ & 2 & ND & ND \\
\hline UBC873 & $(\mathrm{GACA})_{4}$ & 6 & ND & ND \\
\hline$(\mathrm{GACA})_{4}$ & & 6 & 8 & 7.0 \\
\hline$(\mathrm{GATA})_{4}$ & & 0 & 0 & 0 \\
\hline \multicolumn{5}{|l|}{$3^{\prime}$ anchored } \\
\hline$(\mathrm{GA})_{8} \mathrm{C}$ & $(\mathrm{GA})_{8} \mathrm{RGY}$ & 7 & 4 & 5.5 \\
\hline$(\mathrm{GT})_{8} \mathrm{R}$ & $(\mathrm{GT}){ }_{8} \mathrm{RYR} Y$ & 6 & 4 & 5.0 \\
\hline UBC807 & $(\mathrm{AG})_{8} \mathrm{~T}$ & 4 & ND & ND \\
\hline UBC809 & $(\mathrm{AG})_{8} \mathrm{G}$ & 3 & ND & ND \\
\hline UBC 810 & $(\mathrm{GA})_{8} \mathrm{~T}$ & 8 & 5 & 6.5 \\
\hline UBC811 & $(\mathrm{GA})_{8} \mathrm{C}$ & 6 & ND & ND \\
\hline UBC 812 & $(\mathrm{GA})_{8} \mathrm{~A}$ & 0 & ND & $\mathrm{ND}$ \\
\hline UBC 842 & $(\mathrm{GA})_{8} \mathrm{YG}$ & 6 & 6 & 6.0 \\
\hline UBC881 & $(\mathrm{GGGGT})_{4}$ & 0 & ND & ND \\
\hline
\end{tabular}

ND: not determined.

turation and 35 cycles of $94^{\circ} \mathrm{C}$ for $30 \mathrm{~s}, 50^{\circ} \mathrm{C}$ for $30 \mathrm{~s}$ and $72^{\circ} \mathrm{C}$ for $1 \mathrm{~min}$. followed by final extension of $72^{\circ} \mathrm{C}$ for $10 \mathrm{~min}$. The PCR products were analysed in $2.0 \%$ agarose gel containing $0.5 \mu \mathrm{g} / \mathrm{ml}$ ethidium bromides in $0.5 \mathrm{X}$ TBE buffer and run in same buffer at $100 \mathrm{~V}$ for $3 \mathrm{~h}$. The gels were viewed 
Table 4. List of ISSR primers used for the genetic analyses of Allocasuarina and Casuarina species showing number and size range of amplified bands resulted from each primer

\begin{tabular}{|c|c|c|c|c|}
\hline Primer code & $\begin{array}{l}\text { No. of polymorphic } \\
\text { bands }\end{array}$ & $\begin{array}{l}\text { No. of bands from } \\
\text { Allocasuarina species }\end{array}$ & $\begin{array}{l}\text { No. of bands from } \\
\text { Casuarina species }\end{array}$ & Amplification range (bp) \\
\hline \multicolumn{5}{|l|}{$5^{\prime}$ anchored } \\
\hline $\mathrm{R}(\mathrm{CA})_{7}$ & 22 & 13 & 20 & $250-1150$ \\
\hline $\mathrm{Y}(\mathrm{TG})_{7}$ & 17 & 16 & 10 & $200-1100$ \\
\hline $\mathrm{TA}(\mathrm{CAG})_{4}$ & 20 & 14 & 15 & $320-1100$ \\
\hline $\mathrm{CRR}(\mathrm{ATT})_{4}$ & 14 & 11 & 6 & $350-2000$ \\
\hline $\mathrm{RA}(\mathrm{GCT})_{6}$ & 36 & 28 & 14 & $190-1200$ \\
\hline$(\mathrm{GACA})_{4}$ & 26 & 23 & 15 & $800-4000$ \\
\hline \multicolumn{5}{|l|}{$3^{\prime}$ anchored } \\
\hline$(\mathrm{GT})_{8} \mathrm{R}$ & 23 & 21 & 13 & $190-1500$ \\
\hline$(\mathrm{GA})_{8} \mathrm{C}$ & 26 & 19 & 15 & $210-650$ \\
\hline UBC 810 & 36 & 23 & 25 & $900-4000$ \\
\hline UBC 842 & 33 & 28 & 17 & $950-3000$ \\
\hline
\end{tabular}

and photographed over UV light in a BioRad Geldoc system.

FISSR-PCR amplifications were performed on the DNA from the clones of C. equisetifolia L. with the selected primers (Table 5). DNA amplifications were set up in $5 \mu 1$ volume containing $15 \mathrm{ng}$ genomic DNA, 1x PCR buffer, $2.5 \mathrm{mM} \mathrm{MgCl}_{2}, 0.1 \mathrm{mM}$ of each dCTP, dGTP, dTTP and dATP, $0.8 \mu \mathrm{M}$ primer, $0.4 \mu \mathrm{M}$ fluorescent dUTP (TAMRA, Perkin Elmer), 0.5 unit of Taq DNA Polymerase (MBI Fermentas). The amplification conditions were same as in ISSRPCR reactions and the products were run on $5 \%$ polyacrylamide gel with $7 \mathrm{M}$ urea, on an $\mathrm{ABI}$ automated sequencer at a constant voltage of $3000 \mathrm{kV}$ for $7 \mathrm{~h}$.

\section{Data analysis}

The ISSR-PCR bands obtained from the species of casuarinas were scored for the presence (1) or absence (0). A pair-wise similarity matrix was constructed using the Dice similarity coefficient (Sneath \& Sokal, 1973). The relationship between the species was displayed as a dendrogram, constructed using NTSYS-pc software (Rohlf, 1992) based on Unweighed Pair Group Method using Arithmetic averages (UPGMA).

Table 5. ISSR-PCR and FISSR-PCR analysis showing number and size range of bands with 12 clones of C. equisetifolia $\mathrm{L}$

\begin{tabular}{|c|c|c|c|c|c|c|}
\hline \multirow[t]{2}{*}{ Primer code } & \multicolumn{2}{|c|}{ No. of bands amplified } & \multicolumn{2}{|c|}{ No. of polymorphic bands } & \multicolumn{2}{|c|}{ Amplification range (bp) } \\
\hline & ISSR & FISSR & ISSR & FISSR & ISSR & FISSR \\
\hline \multicolumn{7}{|l|}{$5^{\prime}$ anchored } \\
\hline $\mathrm{R}(\mathrm{CA})_{7}$ & 13 & 16 & 7 & 15 & $200-1000$ & $320-900$ \\
\hline $\mathrm{Y}(\mathrm{TG})_{7}$ & 8 & 25 & 8 & 22 & $375-1000$ & $250-690$ \\
\hline $\mathrm{CRR}(\mathrm{ATT})_{4}$ & 20 & 25 & 15 & 20 & $150-1020$ & $150-1200$ \\
\hline $\mathrm{Y}(\mathrm{GCC})_{4}$ & 13 & 24 & 12 & 18 & $250-800$ & $250-1300$ \\
\hline$(\mathrm{GACA})_{4}$ & 9 & 13 & 6 & 12 & $275-780$ & $200-1300$ \\
\hline \multicolumn{7}{|l|}{$3^{\prime}$ anchored } \\
\hline UBC 810 & 13 & 11 & 7 & 8 & $575-2500$ & $880-1500$ \\
\hline$(G T)_{8} R$ & 8 & 17 & 2 & 10 & $340-1000$ & $310-1000$ \\
\hline
\end{tabular}




\section{Results and discussion}

\section{Evaluation of ISSR primers}

Based on the reproducibility and scorable nature of the bands, six di-, three tri- and one tetranucleotide repeat primers were selected for the analysis of 11 species of casuarinas and four di-, two tri- and one tetra-nucleotide repeat based primers were selected for fingerprinting of C. equisetifolia $\mathrm{L}$. clones. The reproducibility of ISSR-PCR amplification pattern was tested with two different DNA polymerase enzymes (MBI Fermentas and Ampli Taq DNA polymerase) on two thermal cyclers (Perkin Elmer Corp., USA and MJ Research Inc., USA). All the runs gave identical amplification profiles (data not shown). Further, the reproducibility of ISSR markers on the DNA from vegetatively propagated material was tested by using five ramets of the clone CPCE890110 and no variation was found in the amplification profile (data not shown).

\section{Distribution of microsatellite motifs in casuarina genome}

The frequency and distribution of different microsatellite motifs in the casuarina genome were analysed using 37 primers on 2 clonal isolates, CHCE890903 and CPCE890301f and 20 primers on two species, A. decaisneana and A. dielsiana. Such information could be useful in designing the experiments for microsatellite capture in casuarinas. The primers comprised of 17 different SSR motifs (Table 3 ). The average number of bands produced by $5^{\prime}$ anchored primers was $4.07 \pm 2.0$ and $3.77 \pm 2.5$ in case of $3^{\prime}$ anchored primers. The di-nucleotide repeat motif based primers revealed relatively higher number of bands $(4.85 \pm 2.15)$ than tri-nucleotide $(3.5 \pm 2.8)$ and tetra-nucleotide repeat motifs $(3.3 \pm 3.8)$. The lone penta-nucleotide repeat primer (GGGGT) did not show any amplification. Among the di-nucleotide repeats, the $(\mathrm{CA})_{n}$ and its complementary nucleotide $(\mathrm{GT})_{n}$ repeat motifs amplified more number of bands with an average of $6.0 \pm 3.5$ and $6.3 \pm 1.8$ respectively. Amplification with the primers based on $(\mathrm{GA})_{n}$ repeats produced $4.6 \pm 2.3$ bands. The relative abundance of di-nucleotide repeats in casuarina appears to be similar to Morns species (Awasthi et al., 2004) and other tropical trees
(Condit \& Hubbell, 1991), where (CA) $)_{n}$ repeats have been found to be more common than $(\mathrm{GA})_{n}$.

\section{Genetic analysis of species}

The amplification profiles obtained with the ten ISSR primers for the six species of Allocasuarina and five species of Casuarina are shown in Table 4. A total number of 253 scorable PCR products was detected in the size range of $190-4000 \mathrm{bp}$. The mean number of bands produced per species was 23. Among the 11 species of casuarinas analysed, all the 253 bands were polymorphic of which 112 bands $(44 \%)$ were found to be species specific. A total of 150 bands (average of 30 per species) were detected in Casuarina species of which 57 bands $(36.0 \%)$ were genus-specific. One DNA fragment of size approximately $320 \mathrm{bp}$ (primer $\mathrm{TA}(\mathrm{CAG})_{4}$ ) was present in all the species of Allocasuarina. Three DNA fragments of size approximately 1550 bp (primer UBC842), 625 bp (primer $(\mathrm{CA})_{7}$ ) and 320 bp (primer RA(GCT) $)_{4}$ ) were present in all the species of Casuarina analysed. Minimum number of bands (42) was observed in A. torulosa and maximum number of bands (63) was observed in A. dielsiana and C. equisetifolia $\mathrm{L}$. The ISSR-PCR profile obtained with 11 species of casuarinas is shown in Figure 2. The pair-wise similarity coefficient ranged between 0.113 (A. littoralis/A. huegelians) and 0.571 (C. cristata/C. cunninghamiand). The average genetic similarity among the species was $0.251 \pm 0.085$. The average genetic similarity among only Casuarina species was $0.366 \pm 0.089$. The dendrogram in Figure 3 illustrates the ability of the ISSR markers in grouping Casuarinaceae species. The clearly dendrogram separated the Allocasuarina and Casuarina genera. Allocasuarina species were distributed in two groups (Al and A2), and all the Casuarina species were grouped together (C). Similar clustering of Casuarina species was obtained by the investigation based on chloroplast matK sequences (Steane et al., 2003).

Identification in C. equisetifolia L. clones

ISSR-PCR of DNA from 12 clones of $C$. equisetifolia L. with seven primers produced a total of 84 bands of which 57 bands $(68 \%)$ were polymorphic (Table 5). The minimum and maximum number of bands observed were 8 (primer $(\mathrm{GT})_{8} \mathrm{R}$ 
168

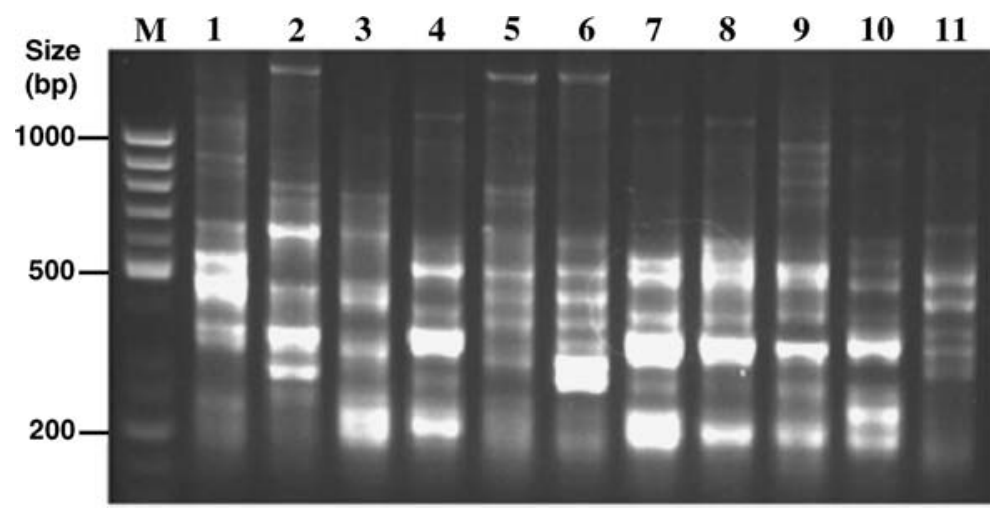

Figure 2. ISSR banding profiles obtained on $2 \%$ agarose gel for the 6 Allocasuarina and 5 Casuarina species with the primer RA(GCT) $)_{6}$. (The numbers represent the order of species given in Table 1) $\mathrm{M}=$ Molecular size marker (100 bp ladder, MBI Fermentas).

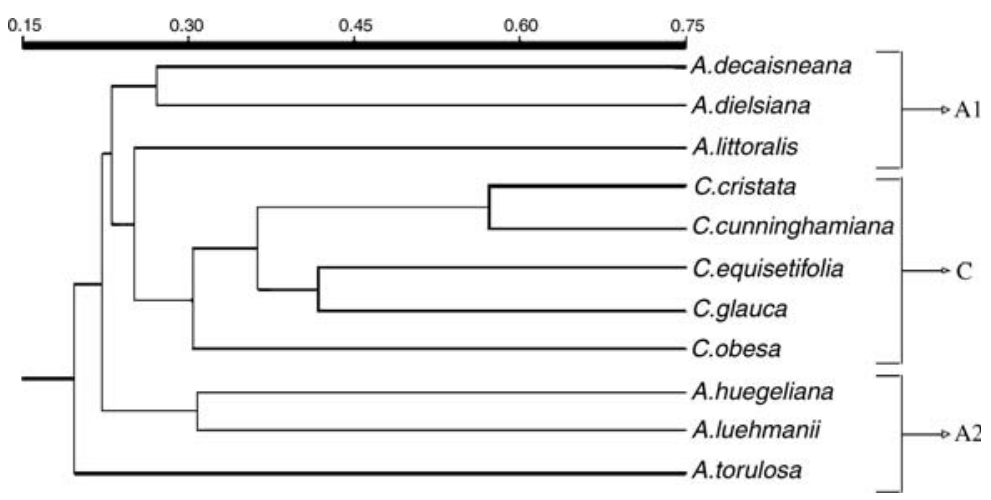

Figure 3. UPGMA dendrogram based on the Dice similarity coefficient illustrating the relationships among the species of Allocasuarina and Casuarina.

and $\left.\mathrm{Y}(\mathrm{TG})_{7}\right)$ and 20 (primer $\left.\left(\mathrm{CRR}(\mathrm{ATT})_{4}\right)\right)$ with an average of $13.6 \pm 4.2$ per primer. The amplification products ranged in size from $150 \mathrm{bp}$ to 2500 bp. Figure 4 shows the DNA profile generated across the 12 clones using the primer CRR $(\mathrm{ATT})_{4}$. The average number of bands $(12.6 \pm 4.7$

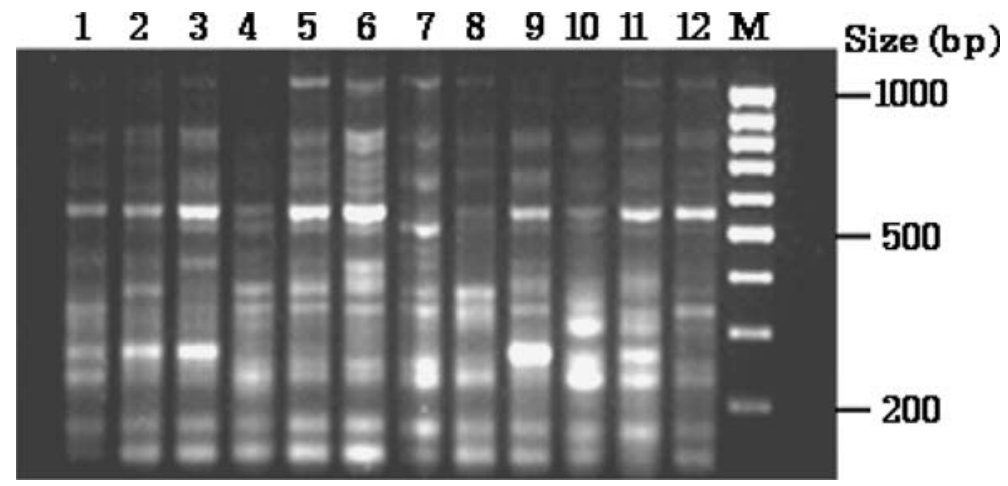

Figure 4. Fingerprints of $C$. equisetifolia L. clones generated by ISSR-PCR on $2 \%$ agarose gel using the primer CRR(ATT) 4 . $\mathrm{M}=$ Molecular size marker (100 bp ladder, MBI Fermentas). 


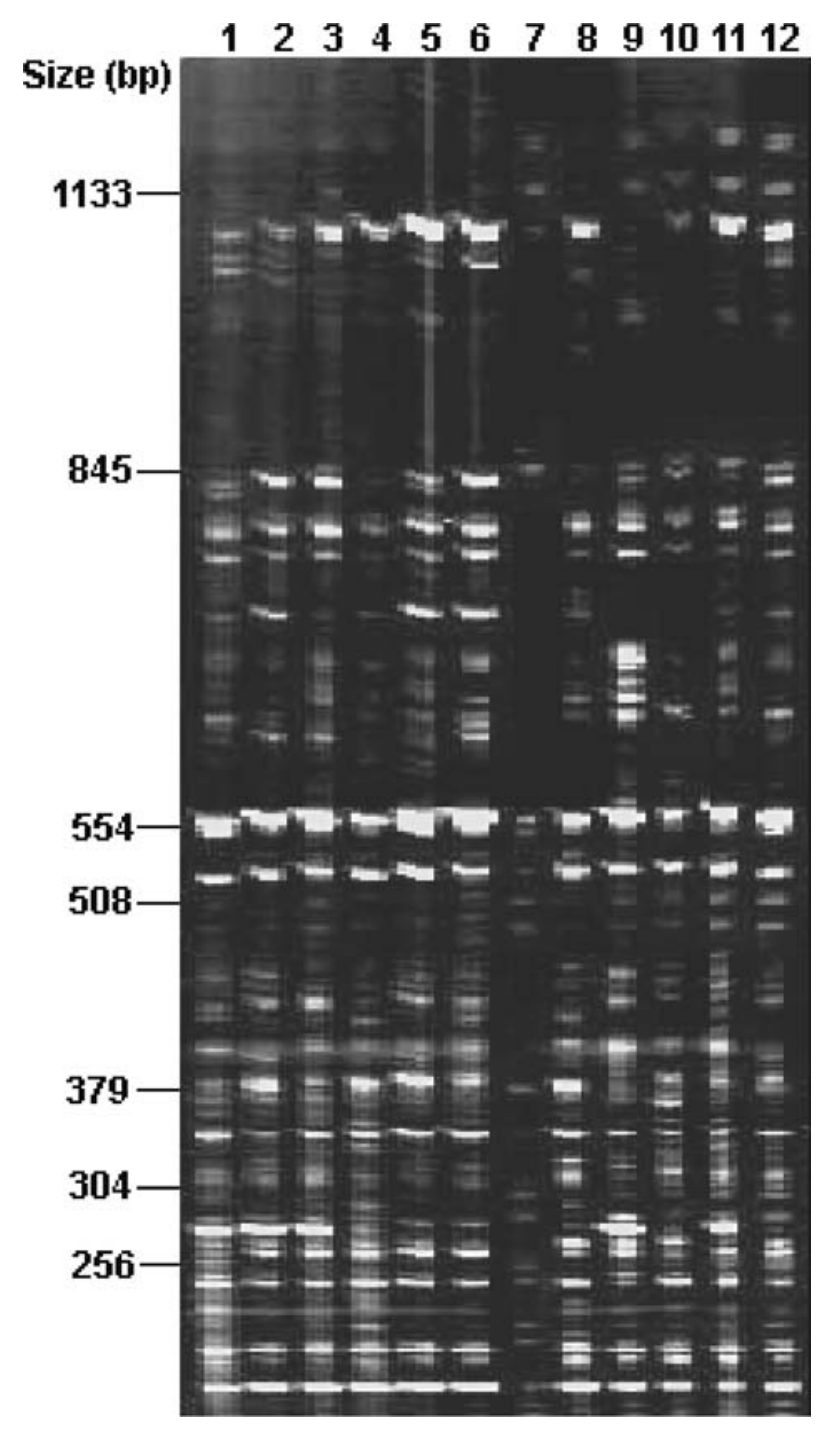

Figure 5. Fingerprints of C. equisetifolia $\mathrm{L}$. clones generated by FISSR-PCR on $5 \%$ polyacrylamide gel using ABI automated sequencer with the primers CRR(ATT) 4 . (The numbers represent the order of species given in Table 2.)

per primer) produced by the $5^{\prime}$ anchored primers was higher than the $3^{\prime}$ anchored primers $(10.5 \pm 3.5)$. The level of polymorphism was $76 \%$ with $5^{\prime}$ anchored primers and $43 \%$ with $3^{\prime}$ anchored primers. The di-, tri- and tetra-nucleotide repeat based primers produced $57 \%, 52 \%$ and $67 \%$ polymorphisms respectively.

In order to enhance the sensitivity of detection of polymorphisms among clones of C. equisetifolia L., we used fluorescent ISSR-PCR (FISSR-PCR) for genotyping. Genomic DNA of the 12 clones was amplified with 7 primers (Table 5). A total of 131 bands were amplified, of which 105 bands
$(80 \%)$ were polymorphic, whereas, in ISSR-PCR the same primers revealed $68 \%$ polymorphisms. The mean number of bands produced per primer was 19.0. The minimum and maximum number of bands produced were 11.0 (UBC810) and 25.0 $\left(\mathrm{Y}(\mathrm{TG})_{7}\right.$ and $\left.\mathrm{CRR}(\mathrm{ATT})_{4}\right)$ respectively. The size of PCR products ranged from $150 \mathrm{bp}$ to $1500 \mathrm{bp}$. The primer UBC 810 produced 11 bands in the size range of $880-1500$ bp and clear separation of bands was lacking, where as, on agarose gel the same primer showed 13 bands with clear separation. The amplification size range of this primer in ISSR-PCR was high (575-2500 bp) which could 
Table 6. Primers and base pair length of ISSR-PCR and FISSR-PCR generated markers for 12 clones of C. equisetifolia L

\begin{tabular}{|c|c|c|c|c|}
\hline Primer code & $\begin{array}{l}\text { ISSR markers } \\
\text { (bp size approx) }\end{array}$ & Clones identified $^{\mathrm{a}}$ & $\begin{array}{l}\text { FISSR markers } \\
\text { (bp size approx.) }\end{array}$ & Clones dentified $^{\mathrm{a}}$ \\
\hline \multicolumn{5}{|l|}{$5^{\prime}$ anchored } \\
\hline $\mathrm{R}(\mathrm{CA})_{7}$ & $1000,900,790$ & $1,2,7,11$ & $680,620,430,350,320$ & $3,5,6,7,9,10,11,12$ \\
\hline $\mathrm{Y}(\mathrm{TG})_{7}$ & $\begin{array}{l}780,750,700,640,340, \\
275\end{array}$ & $1,3,8,10,12$ & $650,600,580,490,425$ & $1,6,7,9,10,12$ \\
\hline $\mathrm{CRR}(\mathrm{ATT})_{4}$ & $\begin{array}{l}615,430,380,300 \\
275,250\end{array}$ & $1-12$ & $\begin{array}{l}700,680,620,555,420, \\
285\end{array}$ & $1-12$ \\
\hline $\mathrm{Y}(\mathrm{GCC})_{4}$ & 360 & nil & $750,520,440,280$ & $1,3,4,8,10,11,12$ \\
\hline$(\mathrm{GACA})_{4}$ & 600,650 & nil & $1000,900,880,650$ & $1,3,4,6,9$ \\
\hline \multicolumn{5}{|l|}{$3^{\prime}$ anchored } \\
\hline UBC 810 & $1200,875,800,775$ & $1,2,5,10$ & $1200,1100,880$ & 3,5 \\
\hline$(\mathrm{GT})_{8} \mathrm{R}$ & 900,1000 & 12 & $1000,660,310$ & $1,3,5,12$ \\
\hline
\end{tabular}

${ }^{\mathrm{a}}$ See Table 2 for clone number codes.

not be resolved on polyacrylamide gel. Although the primer $\mathrm{Y}(\mathrm{GCC})_{7}$ amplified DNA fragments in the size range of $250-1300 \mathrm{bp}$, most of them were in the range of 275-560 bp with clear separation. The pattern of amplification products of CRR(ATT) $)_{4}$ is shown in Figure 5.

For fingerprinting purposes, the ISSR and FISSR bands, which were polymorphic for more than four clones were selected and their sizes are given in Table 6. Amplification profile consisting of fourteen polymorphic markers produced by the individual primer $\mathrm{CRR}(\mathrm{ATT})_{4}$ was sufficient to identify all the twelve clones in both ISSR and FISSR assays (Figure 5). These results demonstrated that ISSR assays could generate ideal markers for fingerprinting. It is thus possible to establish a fingerprint reference library of ISSR and FISSR profile of the 12 clones of $C$. equisetifolia $\mathrm{L}$. Such information will be of use in identification and verification of genotypes in clonal plantations and clonal seed orchards. Since the cost of maintaining clones without identity is very high and mislabeling of clones in plantation is not uncommon (Wheeler \& Jech, 1992; Keil \& Griffin, 1994; Van de Yen \& McNicol, 1995; Scheepers, Eloy \& Briquet, 1997) the use of DNA based methods for clonal verification will be very useful. No sex specific marker could be identified in our study, though the population from which the samples were collected showed near 1:1 male female ratio with 2-3 percent monoecious trees.
The advantages of ISSR markers are well documented in agronomic species (Godwin, Aitken \& Smith, 1997). Genome analysis in woody perennials using ISSR has also been shown to be possible in Douglas fir and Sugi (Tsumura et al., 1996), Citrus (Fang \& Roose, 1997; Fang et al., 1997, 1998), Cocoa (Charters \& Wilkinson, 2000), Larix (Arcade et al., 2000) and Morus (Awasthi et al., 2004). In fingerprinting applications, the molecular method employed should be inexpensive, technically simple yet reliable. In casuarinas, isolation of quality DNA is difficult. Therefore the methodology should require very low quantity (2$5 \mathrm{ng}$ ) of template DNA but able to generate higher level of polymorphism. The present study illustrates the advantages of the FISSR-PCR system for the fingerprinting of $C$. equisetifolia clones generating higher number of bands per assay using very little quantity of template DNA.

\section{Acknowledgement}

This research was funded by the Department of Biotechnology, Ministry of Science \& Technology, Govt. of India.

\section{References}

Ahuja, M.R. \& W.J. Libby, 1993. Clonal Forestry I: Genetics and Biotechnology. Springer, Berlin Heidelberg, New York. 
Ajibade, S.R., N.F. Weeden \& S.M. Chite, 2000. Inter simple sequence repeat analysis of genetic relationships in the genus Vigna. Euphytica 111: 47-55.

Arcade, A., F. Anselin, P. Faivre Rampant, M.C. Lesage, L.E. Pâques \& D. Prat, 2000. Application of AFLP, RAPD and ISSR markers to genetic mapping of European and Japanese larch. Theor. Appl. Genet. 100: 299-307.

Awasthi, A.K., G.M. Nagaraja, G.V. Naik, S. Kanginakudru, K. Thangavelu \& J. Nagaraju, 2004. Genetic diversity and relationships in mulberry (genus Morus) as revealed by RAPD and ISSR marker assays. BMC Genet. 5: 1.

Barlow, B.A., 1959. Chromosome numbers in Casuarinaceae. Aust. J. Bot. 7: 230-237.

Barlow, B.A., 1983. The casuarinas - a taxonomic and biogeographic review, pp. 10-18 in Casuarina Ecology, Management and Utilization, edited by S.J. Midgley, J. Turnbull \& R.D. Johnston. CSIRO, Australia.

Blair, M.W., O. Panaud \& S.R. McCouch, 1999. Inter-simple sequence repeat (ISSR) amplification for analysis of microsatellite motif frequency and fingerprinting in rice (Oryza saliva L.). Theor. Appl. Genet. 98: 780-792.

Broun, P. \& S.D. Tanksley, 1996. Characterisation and genetic mapping of simple sequences in the tomato genome. Mol. Gen. Genet. 250: 39-49.

Chapman, H.M., D. Parh \& N. Oraguzie, 2000. Genetic structure and colonizing success of a clonal, weedy species, Pilosella officinarum (Asteraceae). Heredity 84: 401409.

Charters, Y.M. \& M.J. Wilkinson, 2000. The use of selfpollinated progenies as 'in-groups' for the genetic characterization of cocoa germplasm. Theor. Appl. Genet. 100: $160-166$.

Condit, R. and S.P. Hubbell, 1991. Abundance and DNA sequence of two-base repeat regions in tropical tree genomes. Genome, 34: 66-71.

Doran, J. \& N. Hall, 1983. Notes on Fifteen Australian Casuarina species, pp. 19-52 in Casuarina Ecology, Management and Utilization, edited by S.J. Midgley, J. Turnbull \& R.D. Johnston. CSIRO, Australia.

Doyle, J.J. \& J.L. Doyle, 1990. Isolation of plant DNA from fresh tissue. Focus, 12: 13-15.

Fang, D.Q. \& M.L. Roose, 1997. Identification of closely related citrus cultivars with inter-simple sequence repeat markers. Theor. Appl. Genet. 95: 408-417.

Fang, D.Q., R.R. Krueger \& M.L. Roose, 1998. Phylogenetic relationships among selected Citrus germplasm accessions revealed by inter-simple sequence repeat (ISSR) markers. J. Am. Soc. Hort. Sci. 123: 612-617.

Fang, D.Q., M.L. Roose, R.R. Krueger \& C.T. Federici, 1997. Fingerprinting trifoliate orange germ plasm accessions with isozymes, RFLPs and inter-simple sequence repeat markers. Theor. Appl. Genet. 95: 211-219.

FAO (1995); Forest Resource Assessment, 1990. Tropical forest plantation resources. FAO Forestry paper no. 128 Rome.

Ge, X.J. \& M. Sun, 1999. Reproductive biology and genetic diversity of a cryptoviviparous mangrove Aegiceras corniculatum (Myrtinaceae) using allozyme and inter simple sequence repeat (ISSR) analysis. Mol. Ecol. 8: 20612069.

Gilbert, J.E., R.V. Lewis, M.J. Wilkinson \& P.D.S. Caligari, 1999. Developing an appropriate strategy to assess genetic variability in plant germplasm collections. Theor. Appl. Genet. 98: 1125-1131.

Godwin, I.D., E.A.B. Aitken \& L.W. Smith, 1997. Application of inter-simple sequence repeat (ISSR) markers to plant genetics. Electrophoresis 18: 1524-1528.

Gurumurthi, K. \& H.C.S. Bhandari, 1988. Induction of rooting in cladode cuttings of Casuarina equisetifolia. Curr. Sci. 57: 958-959.

Ho, K.Y., C.H. Ou, J.C. Yang \& J.Y. Hsiao, 2002. An assessment of DNA polymorphisms and genetic relationships of Casuarina equisetifolia using RAPD markers. Bot. Bull. Acad. Sin. 43: 93-98.

Ho, K.Y., J.C. Yang \& J.Y. Hsiao, 2002. An assessment of genetic diversity and documentation of hybridization of Casuarina grown in Taiwan using RAPD markers. Int. J. Plant Sci. 163: 831-836.

Huang, J.C. \& M. Sun, 2000. Genetic diversity and relationships of sweet potato and its wild relatives in Ipomoea series Batatas (Convolvulaceae) as revealed by inter-simple sequence repeat (ISSR) and restriction analysis of chloroplast DNA. Theor. Appl. Gen. 100: 10501060.

Keil, M. \& A.R. Griffin, 1994. Use of random amplified polymorphic DNA (RAPD) markers in the discrimination and verification of genotypes in Eucalyptus. Theor. Appl. Genet. 89: 442-450.

Kumar, A. \& K. Gurumurthi, 2000. Genetic divergence studies on clonal performance of Casuarina equisetifolia. Silvae Genetica, 49: 57-60.

Kumar, L.D., M. Kathirvel, G.V. Rao \& J. Nagaraju, 2001. DNA profiling of disputed chilli samples (Capsicum annum) using ISSR-PCR and FISSR-PCR marker assays. Forensic Sci. Int. 116: 63-68.

Martin, J.P. \& M.D. Sanchez-Yelamo, 2000. Genetic relationships among species of the geneus Diplotaxis (Brassicaceae) using inter-simple sequence repeat markers. Theor. Appl. Genet. 101: 1234-1241.

Moncur, M.W., D.J. Boland \& J.L. Harbard, 1997. Aspects of floral biology of Allocasuarina verticilliata (Casuarinaceae). Aust. J. Bot. 45: 857-869.

Moreno, S., J.P. Martin \& J.M. Ortiz, 1998. Inter-simple sequence repeats PCR for characterization of closely related grapevine germplasm. Euphytica 101: 117-125.

Nagaraju, J., M. Kathirvel, R. Ramesh Kumar, E.A. Siddiq \& S.E. Hasnain, 2002a. Genetic analysis of traditional and evolved Basmati and non-Basmati rice varieties by using fluorescence-based ISSR-PCR and SSR markers. Proc. Natl. Acad. Sci. USA, 99: 5836-5841.

Nagaraju, J., M. Kathirvel, M. Muthulakshmi, E.V. Subbiah \& L.D. Kumar, 2002b. FISSR-PCR- a simple and sensitive assay for high thgoughput genotyping and genetic mapping. Mol. Cellular Probes 16: 67-72.

Pinyopusarerk, K. \& A.P.N. House, 1993. Casuarina: An annotated bibliography of Casuarina equisetifolia, $C$. junghuhniana and C. oligodon. International Center for Research in Agroforestry, Nairobi, Kenya.

Pinyopusarerk, K., E.R. Williams, V. Luangviriyasaeng \& B. Puriyakorn, 1996. Geographic variation in growth and morphological traits of Casuarina equisetifolia, pp. 143-151: in Proc. of 3rd International Casuarina Workshop on Recent Casuarina Research and Development edited 
by K. Pinyopusarerk, J.W. Turnbull \& S.J. Midgley. Vietnam.

Prevost, A. \& M.J. Wilkinson, 1999. A new system of comparing PCR primers applied to ISSR fingerprinting of potato cultivars. Theor. Appl. Genet. 98: 107-112.

Proven, J., W. Powell \& R. Waugh, 1996. Analysis of cultivated potato (Solanum tuberosuni) using inter microsatellite amplification. Genome 39: 767-769.

Rohlf, F.J. 1992. NTSYS-pc: numerical taxonomy and multivariate analysis system, version 1.7. Exeter Software: Setauket, NY.

Salimath, S.S., A.C. de Oliveira, I.D. Godwin \& J.L. Bennetzen, 1995. Assessment of genome origins and genetic diversity in the genus Eleusine with DNA markers. Genome 38: 757-763.

Scheepers, D., M.C. Eloy \& M. Briquet, 1997. Use of RAPD patterns for clone verification and in studying provenance relationships in Norway spruce (Picea abies). Theor. Appl. Genet. 94: 480-485.

Sneath, P.H.A. \& R.R. Sokal, 1973. Numerical taxonomy. The principles and practices of numerical classification. W.H. Freeman, San Francisco.

Sogo, A., H. Setoguchi, J. Noguchi, T. Jaffre \& H. Tobe, 2001. Molecular phylogeny of Casuarinaceae based on $r b c \mathrm{~L}$ and matK gene sequences. J. Plant Res. 114: 259-464.

Steane, D.A., K.L. Wilson, \& R.S. Hill, 2003. Using matK sequence data to unravel the phylogeny of Casuarinaceae. Mol. Phylogenet. Evol. 28: 47-59.
Tautz, D. 1989. Hypervariability of simple sequences as a general source of polymorphic DNA markers. Nucleic Acids Res. 17: 6463-6471.

Tsumura, Y., K. Ohba \& S.H. Strauss, 1996. Diversity and inheritance of Inter-simple sequence repeat polymorphisms in Douglas fir (Pseudotsuga menziesii) and Sugi (Cryptomeria japonica). Theor. Appl. Genet. 92: 40-45.

Van de Yen, W.T.G. \& R. Me Nicol, 1995. The use of RAPD markers for the identification of Sitka Spruce (Picea sitchenis) clones. Heredity 75: 126-132.

Weber, Z. \& P.E. May, 1989. Abundant class of human DNA polymorphisms which can be typed using the polymerase chain reaction. Am. J. Hum. Genet. 44: 388-396.

Wheeler, N.C. \& K.S. Jech, 1992. The use of electrophoretic markers in seed-orchard research. New For. 6: 311-328.

Wilson, K.L. \& L.A.S. Johnson, 1989. Casuarinaceae. Flora of Australia 3: 100-175.

Wolfe, A.D., Q.Y. Xiang \& S.R. Kephart, 1998. Assessing hybridization in natural populations of Penstemon (Scrophulariaceae) using hypervariable inter simple sequence repeat markers. Mol. Ecol. 7: 1107-1125.

Zavodna, M., J. Kraic, G. Paglia, E. Gregova \& M. Morgante, 2000. Differentiation between closely related lentil (Lens cutinaris Medik.) cultivars using DNA markers. Seed Sci. Tech. 28: 217-219.

Zietkiewicz, E., A. Rafalski \& D. Labuda, 1994. Genome fingerprinting by simple sequence repeat (SSR) - anchored polymerase chain reaction amplification. Genomics 20: 176-183. 